\title{
Plasma erythropoietin assay in patients with chronic renal failure
}

\author{
SYLVIA DAVIES ${ }^{1}$, EVELINE GLYNNE-JONES ${ }^{1}$, MARGARET BISSON ${ }^{2}$, AND \\ P. BISSON ${ }^{2}$
} From the Area Department of Pathology, Heavitree, Exeter EX2 $5 A D^{1}$ and the Renal Unit,
Whipton Hospital, Exeter EX1 3RB

SYNOPSIS Using the post-hypoxic mouse method of assay, values for erythropoietin in the plasma of patients with chronic renal failure were equal to, or greater than, normal values. Results suggest that the source of erythropoietin may be primarily extrarenal. Normal renal tissue, provided in the assay by the intact mouse, is required for activation of the hormone. There still remains to be explained the enhanced erythropoietic response to haemorrhage or hypoxia that can occur in anephric man.

For some years it was believed that the plasma of patients with chronic renal failure contained no measurable erythropoietin (Penington, 1961; Brown, 1965). There have been some reports to the contrary (Gallagher et al, 1959; Naets and Wittek, 1968; Mirand and Murphy, 1970). Results similar to our own, though lacking normal control values, have been obtained by Gral et al (1972). The following report presents values for erythropoietin in the plasma of normal subjects and in the plasma of patients with chronic renal failure who were receiving regular haemodialysis.

\section{Material and Methods}

Samples of blood for estimation of normal values were taken from laboratory volunteers and collected into commercial lithium heparin containers (Searle Diagnostic Ltd, High Wycombe). The plasma was separated and used immediately or stored at $-20^{\circ} \mathrm{C}$ until it was required for assay when it was thawed at room temperature before use. Plasma from patients with chronic renal failure was collected similarly just before dialysis.

The blood haemoglobin and the packed cell volume were measured in normal volunteers. In patients with chronic renal failure the blood pressure was recorded to correlate with the erythropoietin assay, and an account was made of all drugs that were given at the time. A full peripheral blood

Received for publication 9 May 1975. picture was obtained with relevant biochemical parameters.

Plasma erythropoietin was measured by the posthypoxic mouse method (Camiscoli and Gordon, 1970; Cotes, 1971). Standard human urinary erythropoietin B was obtained from the National Institute for Biological Standards. Values were expressed as percentage uptake of ${ }^{59} \mathrm{Fe}$ per millilitre dose of plasma in the test animals.

\section{Results}

NORMAL VALUES

Values for erythropoietin in 38 samples of normal plasma were: mean $7 \cdot 11 \pm 6 \cdot 73 \%{ }^{59} \mathrm{Fe}$ uptake per $\mathrm{ml}$. The figures were equivalent to $0.32 \pm 0.28$ units of standard human urinary erythropoietin B. Values for 21 samples of plasma from normal males were $7.43 \pm 6.73 \%{ }^{59} \mathrm{Fe}$ uptake per $\mathrm{ml}$, and for 17 samples from normal females $6.79 \pm 4.42 \%{ }^{59} \mathrm{Fe}$ uptake per $\mathrm{ml}$; males: females $=\mathbf{P}>0.70$.

\section{CHRONIC RENAL FAILURE}

Values for erythropoietin in 30 samples of plasma from 26 patients with chronic renal failure were: mean $7.62 \pm 6.74 \%{ }^{59} \mathrm{Fe}$ uptake per $\mathrm{ml}$; the figures were equivalent to $0.34 \pm 0.28$ units of standard human urinary erythropoietin B (table). There was no significant difference between values for normal plasma and plasma from patients with chronic renal failure $(P>0 \cdot 70)$.

No correlation was found between the values for 


\begin{tabular}{|c|c|c|c|c|c|c|c|}
\hline $\operatorname{Sex}$ & Age & $\begin{array}{l}\text { Blood } \\
\text { Pressure } \\
(k P a)\end{array}$ & $\begin{array}{l}\text { Blood } \\
\text { Urea } \\
(\text { mmol/l) }\end{array}$ & $H b(g / d l)$ & $\begin{array}{l}P C V \\
(\%)\end{array}$ & $E P O$ & Drugs \\
\hline $\begin{array}{l}\mathbf{1} \quad \mathbf{M} \\
\text { Chronic pyelonephritis }\end{array}$ & 41 & $17 \cdot 3 / 10 \cdot 6$ & $29 \cdot 9$ & $6 \cdot 6$ & 21 & $3 \cdot 7$ & Valium \\
\hline $\begin{array}{l}2 \underset{\text { M }}{\mathbf{M}} \\
\text { Malignant hypertensio }\end{array}$ & ${ }^{28}$ & $20 \cdot 0 / 13 \cdot 3$ & $16 \cdot 6$ & $6 \cdot 6$ & 18 & $22 \cdot 6$ & Methyl dopa, propranolol chlorothiazide \\
\hline $\begin{array}{l}3 \\
\text { Glomerular nephritis }\end{array}$ & 40 & $20 \cdot 0 / 11 \cdot 3$ & $26 \cdot 9$ & $8 \cdot 2$ & 25 & $2 \cdot 6$ & $\begin{array}{l}\text { Oxprenolol, clonidine, allopurinol, } \\
\text { Pabrinex }\end{array}$ \\
\hline$\stackrel{4}{4} \stackrel{M}{M}$, & 40 & $17 \cdot 3 / 8 \cdot 6$ & $12 \cdot 6$ & $5 \cdot 9$ & 18 & 05 & Allopurinol \\
\hline $\begin{array}{l}5 \\
\text { Post-malarial nephrosi }\end{array}$ & is 24 & $21 \cdot 3 / 13 \cdot 3$ & $23 \cdot 2$ & $6 \cdot 2$ & 18 & $10 \cdot 1$ & $\begin{array}{l}\text { Chlorothiazide, propranolol, methyl } \\
\text { testosterone }\end{array}$ \\
\hline $\begin{array}{l}6 \\
\text { Chronic pyelonephritis }\end{array}$ & 36 & $18 \cdot 6 / 10 \cdot 6$ & $23 \cdot 4$ & $7 \cdot 0$ & 20 & $3 \cdot 1$ & Nil \\
\hline $\begin{array}{l}7 \\
\text { Polycystic kidneys }\end{array}$ & 37 & $18 \cdot 6 / 12 \cdot 0$ & $26 \cdot 5$ & $12 \cdot 5$ & 38 & $5 \cdot 5$ & Nil \\
\hline $\begin{array}{c}8 \\
\text { Obstructive uropathy }\end{array}$ & 59 & $17 \cdot 3 / 12 \cdot 0$ & $16 \cdot 6$ & $9 \cdot 5$ & 27 & $\begin{array}{c}19 \cdot 8 \\
14 \cdot 9\end{array}$ & Nil \\
\hline$\stackrel{9}{\mathbf{9}} \stackrel{\text { M }}{\text { 'End stage kidney': red }}$ & 25 cell volume & $\begin{array}{l}10 \cdot 6 / 5 \cdot 3 \\
21 \mathrm{ml} / \mathrm{kg}\end{array}$ & $\begin{array}{l}11 \cdot 8 \\
; \text { plasma } v\end{array}$ & $\begin{array}{l}13.9 \\
\text { Ime } 44 \mathrm{ml} / \mathrm{kg}\end{array}$ & 42 & $6 \cdot 2$ & Nil \\
\hline $\begin{array}{l}10 \quad M \\
\text { 'End stage kidney' }\end{array}$ & 33 & $21 \cdot 3 / 10 \cdot 6$ & $28 \cdot 7$ & $9 \cdot 0$ & 26 & $14 \cdot 3$ & Methyl testosterone \\
\hline $\begin{array}{l}11 \quad M \\
\text { Fanconi syndrome }\end{array}$ & 21 & $16 \cdot 0 / 9 \cdot 3$ & $19 \cdot 9$ & $5 \cdot 8$ & 17 & $0 \cdot 3$ & Methyl testosterone, Decadurabolin \\
\hline $\begin{array}{l}12 \quad \text { M } \\
\text { Obstructive uropathy: }\end{array}$ & $\begin{array}{l}56 \\
\text { intramuscula }\end{array}$ & $\begin{array}{l}16 \cdot 6 / 11 \cdot 4 \\
\text { lar haemorr }\end{array}$ & $\begin{array}{r}14 \cdot 9 \\
\text { rhage }\end{array}$ & $4 \cdot 3$ & 14 & $\begin{array}{l}21 \cdot 3 \\
22 \cdot 9\end{array}$ & Methyl testosterone \\
\hline $\begin{array}{l}13 \quad \text { M } \\
\text { Post-malarial nephrosi }\end{array}$ & $\begin{array}{l}42 \\
\text { is: }\end{array}$ & $\begin{array}{l}16 \cdot 0 / 11 \cdot 4 \\
\text { icosis }\end{array}$ & $19 \cdot 9$ & $9 \cdot 1$ & 27 & 9.3 & $\begin{array}{l}\text { Carbimazole, allopurinol propranolol, } \\
\text { Decadurabolin }\end{array}$ \\
\hline $\begin{array}{l}14 \quad M \\
\text { Alport's syndrome }\end{array}$ & 22 & $21 \cdot 3 / 113$ & $16 \cdot 6$ & $5 \cdot 9$ & 18 & $4 \cdot 7$ & Propranolol \\
\hline $\begin{array}{l}15 \quad M \\
\text { Alport's syndrome: tw }\end{array}$ & in to No. $14^{1}$ & $4^{18 \cdot 6 / 12 \cdot 8}$ & $12 \cdot 6$ & $6 \cdot 6$ & 19 & $6 \cdot 0$ & $\begin{array}{l}\text { Propranolol, Decadurabolin } \\
\text { Methyl testosterone }\end{array}$ \\
\hline $\begin{array}{l}16 \quad \text { M } \\
\text { Membrano-proliferativ }\end{array}$ & $\begin{array}{l}45 \\
\text { ve nephritis }\end{array}$ & $21 \cdot 3 / 15 \cdot 7$ & $29 \cdot 9$ & $9 \cdot 7$ & 29 & $5 \cdot 2$ & Propranolol, allopurinol \\
\hline $\begin{array}{l}17 \quad M \\
\text { Haemolytic-uraemic sy }\end{array}$ & $\begin{array}{l}16 \\
\text { yndrome: ane }\end{array}$ & $\begin{array}{l}16 \cdot 0 / 8 \cdot 0 \\
\text { lephric }\end{array}$ & $21 \cdot 6$ & $7 \cdot 5$ & 23 & 6.0 & Propranolol, allopurinol \\
\hline $\begin{array}{l}18 \quad \text { M } \\
\text { Polycystic kidneys }\end{array}$ & 56 & $18 \cdot 6 / 12 \cdot 0$ & $16 \cdot 6$ & $8 \cdot 8$ & 24 & $1 \cdot 2$ & Methyl testosterone \\
\hline $\begin{array}{l}19 \quad \text { M } \\
\text { Proliferative nephritis }\end{array}$ & 47 & $24 \cdot 0 / 13 \cdot 3$ & $29 \cdot 9$ & $7 \cdot 4$ & 20 & $2 \cdot 2$ & $\begin{array}{l}\text { Prednisolone, cyclophosphamide } \\
\text { bethanidine }\end{array}$ \\
\hline $\begin{array}{l}20 \quad \text { F } \\
\text { Proliferative nephritis }\end{array}$ & 23 & $20 \cdot 0 / 12 \cdot 0$ & $13 \cdot 3$ & $7 \cdot 2$ & 21 & 6.6 & Cyclophosphamide, propranolol \\
\hline $\begin{array}{l}21 \quad F \quad F \\
\text { Analgesic nephropathy }\end{array}$ & $y^{30}$ & $200 / 13 \cdot 5$ & $10 \cdot 3$ & $5 \cdot 8$ & 17 & $5 \cdot 3$ & Valium \\
\hline $\begin{array}{l}22 \\
\text { Post-irradiation : unilat }\end{array}$ & $\begin{array}{l}30 \\
\text { teral kidney }\end{array}$ & $18 \cdot 6 / 11 \cdot 4$ & $8 \cdot 3$ & $5 \cdot 6$ & 18 & $9 \cdot 7$ & Nil \\
\hline $\begin{array}{l}23 \quad \text { F } \\
\text { Lupus erythematosus }\end{array}$ & 37 & $17 \cdot 3 / 13 \cdot 3$ & $29 \cdot 9$ & $6 \cdot 4$ & 18 & $1 \cdot 6$ & Prednisolone, imuran, Decadurabolin \\
\hline $\begin{array}{l}24 \quad \text { F } \\
\text { Red cell volume } 29 \mathrm{ml} / \\
\text { Malignant hypertensior }\end{array}$ & $\begin{array}{l}\text { 53(a) } \\
\text { 1/kg: plasma } \\
\text { 53(b) } \\
\text { on }\end{array}$ & $\begin{array}{l}22 \cdot 0 / 13 \cdot 3 \\
\text { volume } 56 \\
24 \cdot 6 / 11 \cdot 3\end{array}$ & $\begin{array}{l}11 \cdot 6 \\
\mathrm{ml} / \mathrm{kg}: \text { ar } \\
33 \cdot 2\end{array}$ & $\begin{array}{l}11.8 \\
\text { al oxygen } 9.3 \\
8.3\end{array}$ & $\begin{array}{r}39 \\
\mathrm{kPa} \\
19\end{array}$ & $\begin{array}{r}3 \cdot 1 \\
10 \cdot 7\end{array}$ & Bethanidine \\
\hline $\begin{array}{l}25 \quad \mathbf{F} \\
\text { 'End stage kidney' }\end{array}$ & 36 & $18 \cdot 6 / 12 \cdot 8$ & $23 \cdot 2$ & $7 \cdot 8$ & 22 & 0.0 & Nil \\
\hline $\begin{array}{l}26 \quad \text { F } \\
\text { Malignant hypertensio }\end{array}$ & $\begin{array}{l}38 \\
\text { on: pre-nephr }\end{array}$ & $\begin{array}{l}16 \cdot 0 / 6 \cdot 6 \\
\text { rectomy }\end{array}$ & $14 \cdot 9$ & $4 \cdot 3$ & 12 & $6 \cdot 2$ & Nil \\
\hline
\end{tabular}

Table Investigation of plasma from 26 patients with chronic renal failure

EPO = plasma erythropoietin $\%{ }^{50} \mathrm{Fe}$ uptake per $\mathrm{ml}$

All patients received oral iron and folic acid and injections of Neocytamen.

Normal values for blood haemoglobin and packed cell volume:

males $\mathrm{Hb} 15 \cdot 3 \pm 0.8 \mathrm{~g} / \mathrm{dl}:$ PCV $45 \cdot 3 \pm 3.2 \%$

females $\mathrm{Hb} 14 \cdot 0 \pm 1 \cdot 5 \mathrm{~g} / \mathrm{dl}: \operatorname{PCV} 41 \cdot 2 \pm 4 \cdot 0 \%$. 
the blood haemoglobin $(r=0 \cdot 10)$, packed cell volume $(r=0.12)$ or blood urea $(r=0.13)$ and the plasma erythropoietin. There was no demonstrable difference in values for the blood haemoglobin or plasma erythropoietin values in patients who were treated with methyl testosterone compared with others who did not receive methyl testosterone $(P>0.2:>0.5)$. Some of the patients showed unusual features and these are described below.

\section{Patient 9}

This man suffered an accidental intramuscular haemorrhage and his blood haemoglobin fell to $4.3 \mathrm{~g} / \mathrm{dl}$. At the same time the plasma erythropoietin measured 21.3 and $22.9 \%{ }^{59} \mathrm{Fe}$ uptake per $\mathrm{ml}$, in two separate assays.

\section{Patient 24}

Eighteen months after bilateral nephrectomy for the management of malignant hypertension, this woman had a blood haemoglobin of $11.8 \mathrm{~g} / \mathrm{dl}$, and packed cell volume $39 \%$. Blood volume studies showed a red cell volume of $24.8 \mathrm{ml} / \mathrm{kg}$ (normal $20-30 \mathrm{ml} / \mathrm{kg}$ ) with plasma volume $56 \mathrm{ml} / \mathrm{kg}$ (normal 40-50 $\mathrm{ml} / \mathrm{kg}$ ). The plasma erythropoietin measured $3 \cdot 2$ and $3.0 \%{ }^{59} \mathrm{Fe}$ uptake per $\mathrm{ml}$ in two separate assays. There was no evidence of pulmonary insufficiency but the arterial oxygen saturation was 9.3 $\mathrm{kPa}$ (normal 13.3-16.6 kPa). Twelve weeks later the blood haemoglobin was $8.3 \mathrm{~g} / \mathrm{dl}$; plasma erythropoietin then measured $10.7 \%{ }^{59} \mathrm{Fe}$ uptake per ml.

No clinical evidence of haemorrhage or hypoxia was found in patients 2 and 8 to account for the high values for the plasma erythropoietin. Patient 9 had relatively high values for the blood haemoglobin, packed cell volume, and red cell volume with a normal plasma erythropoietin level; again, no reason could be found for the results.

\section{Discussion}

\section{NORMAL VALUES}

Although there are many reports of values for plasma erythropoietin in patients with various haematological disorders, few series include normal values. Those using the post-hypoxic mouse method of assay include Bourgoignie et al (1968) with values in 12 normal subjects of $0.60 \pm 0.05 \%{ }^{59} \mathrm{Fe}$ uptake per $\mathrm{ml}$, and Whitcomb et al (1970) with values in four normal subjects of $0.4-1 \cdot 2 \%{ }^{59} \mathrm{Fe}$ uptake per $\mathrm{ml}$. Hasewaga et al (1968), using the starved rat method of assay, obtained levels of $9.6 \pm 2.0 \%{ }^{59} \mathrm{Fe}$ uptake per $\mathrm{ml}$. It is difficult to correlate the results of haemagglutination-inhibition assay with biological assay. However, Lange et al (1969) measured serum erythropoietin levels in a total of 141 normal blood donors and obtained values of 0.0035 to 0.60 units of erythropoiesis stimulating factor (ESF) per ml.

\section{CHRONIC RENAL FAILURE}

Only one of our patients had no measurable erythropoietin in the plasma; in 25 , the range of values was $0.5-22.9 \%{ }^{59} \mathrm{Fe}$ uptake per $\mathrm{ml}$.

Adamson et al (1968) studied 24 patients with chronic renal failure and reported plasma erythropoietin values less than normal in 17 , normal in four, and increased above normal in three. Naets and Wittek (1968) reported a value for plasma erythropoietin of $19.3 \%{ }^{59} \mathrm{Fe}$ uptake per $\mathrm{ml}$ in one of 11 patients with chronic renal failure. In five anephric subjects who were investigated by Mirand and Murphy (1970) values for plasma erythropoietin showed a range of $0 \cdot 78-25 \cdot 2 \%{ }^{59} \mathrm{Fe}$ uptake per $\mathrm{ml}$.

Blood transfusions were avoided in the patients in our series. It was shown that plasma erythropoietin levels were greater in non-transfused patients with chronic renal failure (Gral and Schroth, 1970). The same workers (Gral et al, 1972) measured plasma erythropoietin in 73 patients with chronic renal failure; their results were shown in the form of a graph and expressed in Naperian logarithms with a range of $0.4-2.6 \%{ }^{59} \mathrm{Fe}$ uptake per $\mathrm{ml}$. When our values were converted to the same terms, the figures were similar to those of Gral et al.

In our patients, the administration of methyl testosterone produced no remarkable effect on values for the blood haemoglobin, packed cell volume, or plasma erythropoietin levels. Moreover, when equivalent amounts of testosterone to normal male physiological levels were added to normal female plasma and included in a standard assay, no increase in $\%{ }^{59} \mathrm{Fe}$ uptake was found although other workers have reported stimulating effects upon erythropoiesis by androgens in experimental animals (Meinecke and Crafts, 1968). DeGowin et al (1970) described two patients with chronic renal failure who were treated with testosterone and reported increased values for the plasma erythropoietin. However, blood transfusions were discontinued during the test period so that the results could be compared with those of Gral and Schroth in nontransfused patients who had not received testosterone. However, clinical response to testosterone therapy in patients with chronic renal failure has been reported by Shaldon et al (1970).

The effects of hypoxia and haemorrhage in two patients in our series confirmed the results of experimental studies by Fried and Gurney (1968), showing that erythropoietic response can occur in these conditions in the anephric state. 


\section{Conclusion}

We have been able to obtain values for plasma erythropoietin in normal subjects and in patients with chronic renal failure. That we have done so may be due to the fact that our biological material is more sensitive to erythropoietin than that of other workers since our method of assay follows accepted procedures.

Zanjani et al (1972) outlined the function of renal erythropoietic factor (REF) as activator of erythropoietin. So far, REF has not been identified. If, as we have shown, patients with renal failure do have erythropoietin in their plasma in normal amounts, it would seem important for the future to isolate and identify renal erythropoietic factor as a possible therapeutic agent in the management of the anaemia of renal failure.

We are very grateful to the technical staff of the laboratory for providing us with samples of normal plasma for assay. We should like to thank Dr Mary Cotes, National Institute for Biological Standards, for her generous help and advice with the method of assay; and Dr G. H. Hall, Director, Renal Unit, Whipton Hospital, for his help and cooperation in providing patients for study.

This work was supported by research grants from the South Western Regional Hospital Board and the National Kidney Research Fund.

\section{References}

Adamson, J. W., Eschbach, J., and Finch, C. A. (1968). The kidney and erythropoiesis. Amer. J. Med., 44, 725-733.

Bourgoignie, J. J., Gallagher, N. I., Perry, H. M., Kurz, L., Warnecke, M. A., and Donati, R. M. (1968). Renin and erythropoietin in normotensive and in hypertensive patients. J. Lab. clin. Med., 71, 523-536.

Brown, R. (1965). Plasma erythropoietin in chronic uraemia. Brit. med. J., 2, 1036-1038.

Camiscoli, J. F., and Gordon, A. S. (1970). Bioassay and standardization of erythropoietin. In Regulation of Haematopoiesis, edited by A. S. Gordon, pp. 369-393. Appleton-Century-Crofts, New York.

Cotes, P. M. (1971). Measurement of erythropoietin. In
Kidney Hormones, edited by J. W. Fisher, pp. 243-267. Academic Press, New York.

DeGowin, R. L., Lavender, A. R., Forland, M., Charleston, D., and Gottschalk, A. (1970). Erythropoiesis and erythropoietin in patients with chronic renal failure treated with hemodialysis and testosterone. Ann. intern. Med., 72, 913-918.

Fried, W. and Gurney, C. W. (1968). The erythropoieticstimulating effects of androgens. Ann. N.Y. Acad. Sci., 149, 356-365.

Gallagher, N. I., McCarthy, J. M., Hart, K. T., and Lange, R. D. (1959). Evaluation of plasma erythropoietic-stimulating factors in anemic uremic patients. Blood, 14, 662667.

Gral, T., and Schroth, P. (1970). Transfusions, transferrin saturation and erythropoietic activity in long-term hemodialysed uremic patients. Amer. J. med. Sci., 260, 230-236.

Gral, T., Schroth, P., and Maxwell, M. H. (1972). Plasma erythropoietic activity in patients in chronic dialysis with or without kidneys. Trans. Amer. Soc. artif. intern. Org., 18, 291-294.

Hasewaga, M., Matsuki, Y., Ozawa, S., and Ando, Y. (1968). जे The role of erythropoietin in aplastic anemia: some aspects for etiology and treatment of aplastic anemia. Keio J. Med., 17, 109-123.

Lange, R. D., McDonald, T. P., and Jordan, T. (1969). Antisera to erythropoietin: partial characterization of two different antibodies. J. Lab. clin. Med., 73, 78-90.

Meinecke, H. A. and Crafts, R. C. (1968). Further observations of the mechanism by which androgens and growth hormone influence erythropoiesis. Ann. N.Y. Acad. Sci. 149, 298-307.

Mirand, E. A. and Murphy, G. P. (1970). Extrarenal erythro poietin activity in man and experimental animals. II Regulation of Haematopoiesis, edited by A. S. Gordoto pp. 495-518. Appleton-Century-Crofts, New York.

Naets, J. P. and Wittek, M. (1968). Presence of erythropoietin in the plasma of one anephric patient. Blood, 31, 249-251.

Penington, D. G. (1961). The role of the erythropoietic hormone in anaemia. Lancet, 1, 301-306.

Shaldon, S., Lansdell, J. A., Koch, K. M., Opperman, F., Patyna, W., Schaefer, G., Schoeppe, W., and Werner, E. (1970). The use of androgens in the treatment of the anaemia of patients on regular dialysis. Proc.Europ. Dialysis Transplant Ass., 7, 94.

Whitcomb, W. H., Joern, A. T., Guenter, C. A., Moore, M., Shurley, J. T., and Pierce, C. M. (1970). Effect of the south polar plateau on plasma and urine erythropoietin levels. Arch. intern. Med., 125, 638-645.

Zanjani, E. D., Gidari, A. S., Gordon, A. S., and Peschle, C. (1972). Further studies on the mechanism of erythropoietin formation by the kidney. In Regulation of Erythropoiesis, edited by A. S. Gordon, M. Conderelli, and C. Peschle, pp. 205-215. Il ponte Publishing House, Milan. 